\title{
RANGE EXPANSION OF AN INVASIVE ALIEN SPECIES, CHINESE SLEEPER, PERCCOTTUS GLENII DYBOWSKI, 1877 (TELEOSTEI: ODONTOBUTIDAE) IN THE VISTULA RIVER DRAINAGE
}

\author{
Michał NOWAK*, Włodzimierz POPEK, and Piotr EPLER \\ Department of Ichthyobiology and Fisheries, Agricultural University of Krakow, Poland
}

Nowak M., Popek W., Epler P. 2008. Range expansion of an invasive alien species, Chinese sleeper, Perccottus glenii Dybowski, 1877 (Teleostei: Odontobutidae) in the Vistula River drainage. Acta Ichthyol. Piscat. 38 (1): 37-40.

\begin{abstract}
In October 2007 an invasive alien species, the Chinese sleeper, Perccottus glenii Dybowski, 1877 (known also as the Amur sleeper), was recorded in carp ponds in Kraków-Mydlniki (southern part of Vistula River drainage). As far as we know, this is the uppermost site in the Polish part of the Vistula River drainage. Thirty-six individuals of $P$. glenii were collected during fishery works. Basic morphometric measurements were obtained, following the commonly accepted procedures, in order to describe the general body shape of $P$. glenii.
\end{abstract}

Keywords: Chinese sleeper, Amur sleeper, Perccottus glenii, invasive species, alien species, Vistula River drainage, morphometry

The Chinese sleeper (known also as the Amur sleeper, rotan; or trawianka in Polish), Perccottus glenii Dybowski, 1877 (Odontobutidae) is a non-native species of Polish ichthyofauna (the terms such as: "non-native", "indigenous", or "alien" species were used herein according to Copp et al. (2005)). P. glenii is indigenous to the Far East of Russia, north-east China, and northern North Korea (Berg 1949, Bogutskaya and Naseka 2002, Koščo et al. 2003, Reshetnikov 2004). Within the 20th century, due to intentional and non-intentional introductions, it became widespread throughout Asia and central-eastern Europe (Bogutskaya and Naseka 2002, Reshetnikov 2004).

In the Vistula River drainage $P$. glenii was recorded for the first time in 1988 by Movchan in the Vishnya River (a tributary of the San River) in the territory of Ukraine (Bogutskaya and Naseka 2002). In Poland it was found for the first time in 1993-1994 in an oxbow lake of the Vistula River near Dęblin (Antychowicz 1994). Terlecki (1995) refers also its presence in the Vistula River, near the town of Kazimierz Dolny. Since then, P. glenii has been caught in several places within the Vistula River drainage (Terlecki and Pałka 1999, Andrzejewski and Mastyński 2004, Kostrzewa et al. 2004). Terlecki (2000) listed 6 isolated sites in Vistula and Western Bug drainages where this species can be found. According to Terlecki (1995, 2000), Terlecki and Pałka (1999), Andrzejewski and Mastyński (2004), Kostrzewa et al. (2004), as well as the results of the presently reported study, there have been about 15 known and confirmed localities within the Vistula River drainage (Poland), where the species occurs (Fig. 1).

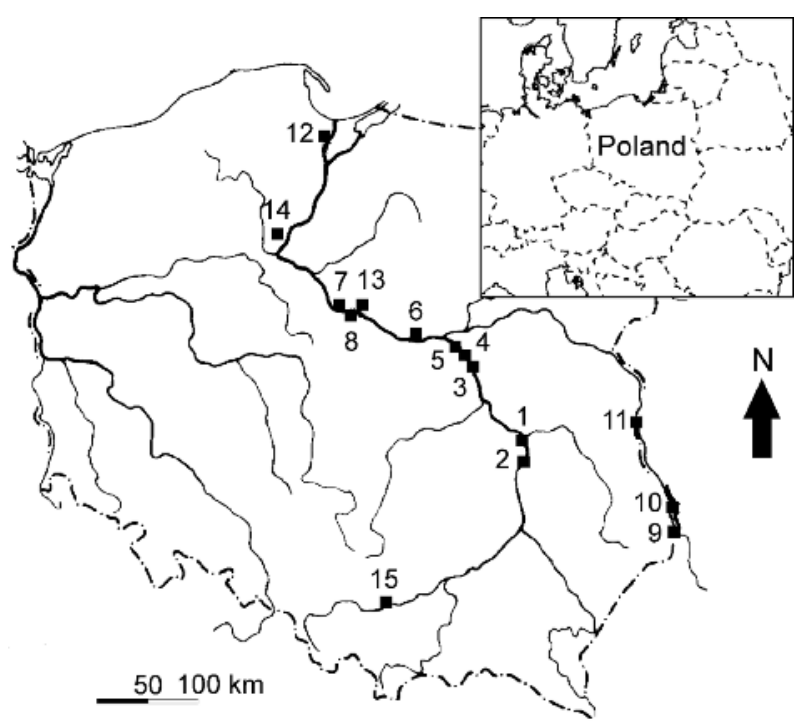

Fig. 1. Occurrence of the Perccottus glenii in Poland: 1, Antychowicz (1994); 2, Terlecki (1995); 3-5, Woźniewski (1997); 6-7, Kakareko (1999); 8, Kostrzewa et al. (1999); 9-13, Kostrzewa et al. (2004); 12, Wiśniewolski and Woźniewski (pers. comm.); 14, Andrzejewski and Mastyński (2004); 15, Rudawa river in Kraków, presently reported study (2007)

\footnotetext{
* Correspondence: Dr Michał Nowak, Katedra Ichtiobiologii i Rybactwa Uniwersytet Rolniczy im. Hugona Kołłątaja w Krakowie, ul. Spiczakowa 6, 30-199 Kraków,
} Poland, phone: +48 1263751 76, fax: +48 1263859 79, e-mail: mikhael.nowak@gmail.com 
However, Witkowski (2003) estimated that the total number of P. glenii sites in Poland reaches 1000. In 2002 Andrzejewski and Mastyński (2004) speculated that $P$. glenii had broken the borderline of the Vistula River drainage and it will probably continue its dispersal into the western parts of Europe. As far as we know the species has not been recorded in the Odra (Oder) River drainage, although such assumption cannot be rejected (Freyhof 2003).

During the last decade a fast spreading of $P$. glenii in south-eastern Europe has been noticed. In 1998 the species was recorded in Latvia (Plikšs and Aleksejevs 1998). In the same year it was collected in the Gulf of Finland (Panov et al. 1999). During the last few years Chinese sleeper has been consecutively found in the Tisza River drainage area in Ukraine, Slovakia, Hungary, and Romania (Koščo et al. 2003, Hegediš et al. 2007) and in Danube River within the territory of Serbia and Bulgaria (Jurajda et al. 2006, Hegediš et al. 2007). P. glenii was also found in White Sea and Arctic Ocean basins (Bogutskaya and Naseka 2002; Koščo et al. 2003). Furthermore the species spreads through the Asian part of Russia (Bogutskaya and Naseka 2002, Reshetnikov 2004).

In the middle of October 2007 more than 40 individuals of $P$. glenii were collected during fishery works in the "Podkamycze II" carp pond (the Experimental Fisheries
Station "Mydlniki", Department of Ichthyobiology and Fisheries, Agricultural University of Krakow). This was the first time the species was reported in the area (lat $50^{\circ} 03^{\prime} \mathrm{N}$, long $\left.19^{\circ} 56^{\prime} \mathrm{E}\right)$. The fish were harvested in the pond with well developed water vegetation, with predominant species such as: Phragmites australis, Glyceria aquatica, Typha latifolia, Potamogeton perfoliatus, and P. crispus. Chinese sleeper co-occurred with the following fish species: common carp, Cyprinus carpio (age 2+); Prussian carp, Carassius gibelio; and pikeperch, Sander lucioperca (2+). This site seems to be the uppermost limit of its distribution area in the Vistula River drainage within the territory of Poland.

Thirty-six specimens of $P$. glenii were anaesthetised with Propiscin and preserved in 4\% formaldehyde. Then, in order to describe better the general body shape of the collected fish, 22 morphometric- and 6 meristic characteristics were measured, according to Hubbs and Lagler (1947) (Fig. 2, Tables 1, 2). As far as we know, such characteristic has never been used in Poland for such purposes. Standard length (SL) and head length (HL) were measured from the tip of the snout (upper jaw) to, respectively, posterior end of hypural complex (localised by bending out the caudal fin) and posteriormost point of the opercular membrane. All measurements were taken as straight lines, by the "point-to-point" method.

Table 1

Morphometric characteristics of Perccottus glenii caught in ponds in Kraków-Mydlniki $(n=36)$

\begin{tabular}{|c|c|c|c|c|}
\hline No. & Character & Range & Mean & $s$ \\
\hline 1 & Total length (TL) $[\mathrm{mm}]$ & $77.7-106.5$ & 93.68 & 4.86 \\
\hline 2 & Standard length (SL) [mm] & $61.4-88.0$ & 75.98 & 4.24 \\
\hline \multicolumn{5}{|c|}{$\%$ of SL } \\
\hline 3 & Head length (HL) & $33.47-37.87$ & 35.63 & 1.10 \\
\hline 4 & Maximum body depth & $23.68-29.41$ & 26.26 & 1.16 \\
\hline 5 & Depth of caudal peduncle & $11.48-13.54$ & 12.56 & 0.57 \\
\hline 6 & Body width at dorsal fin origin & $16.76-20.37$ & 18.39 & 0.91 \\
\hline 7 & Width of caudal peduncle at anal fin insertion & $9.09-11.10$ & 10.17 & 0.50 \\
\hline 8 & Predorsal length & $40.22-44.35$ & 42.57 & 1.13 \\
\hline 9 & Postdorsal length & $23.18-28.97$ & 26.06 & 1.36 \\
\hline 10 & Prepelvic length & 34.64-38.07 & 36.41 & 1.02 \\
\hline 11 & Preanal length & $60.48-65.36$ & 63.48 & 1.19 \\
\hline 12 & Pelvic to anal-fin origin distance & $26.67-30.86$ & 28.74 & 0.90 \\
\hline 13 & Length of caudal peduncle & $23.55-28.21$ & 26.07 & 1.01 \\
\hline \multicolumn{5}{|c|}{$\%$ of $\mathrm{HL}$} \\
\hline 14 & Snout length & $22.18-26.74$ & 24.65 & 1.02 \\
\hline 14 & Horizontal eye diameter, the greatest fleshy diameter & $15.19-19.61$ & 16.56 & 1.06 \\
\hline 16 & Postorbital length & $57.48-65.10$ & 61.07 & 1.45 \\
\hline 17 & Head depth at eye centre & $40.73-47.78$ & 43.81 & 1.69 \\
\hline 18 & Head depth at nape & $59.26-70.71$ & 64.13 & 2.64 \\
\hline 19 & Head width at posterior margin of preopercle & $49.63-60.71$ & 55.30 & 2.76 \\
\hline 20 & Interorbital width, the least fleshy width & $20.80-25.93$ & 24.00 & 1.30 \\
\hline 21 & Upper jaw length & $29.93-38.28$ & 35.41 & 1.76 \\
\hline 22 & Lower jaw length & $30.66-39.84$ & 36.84 & 1.75 \\
\hline
\end{tabular}

$s$, standard deviation of the mean. 


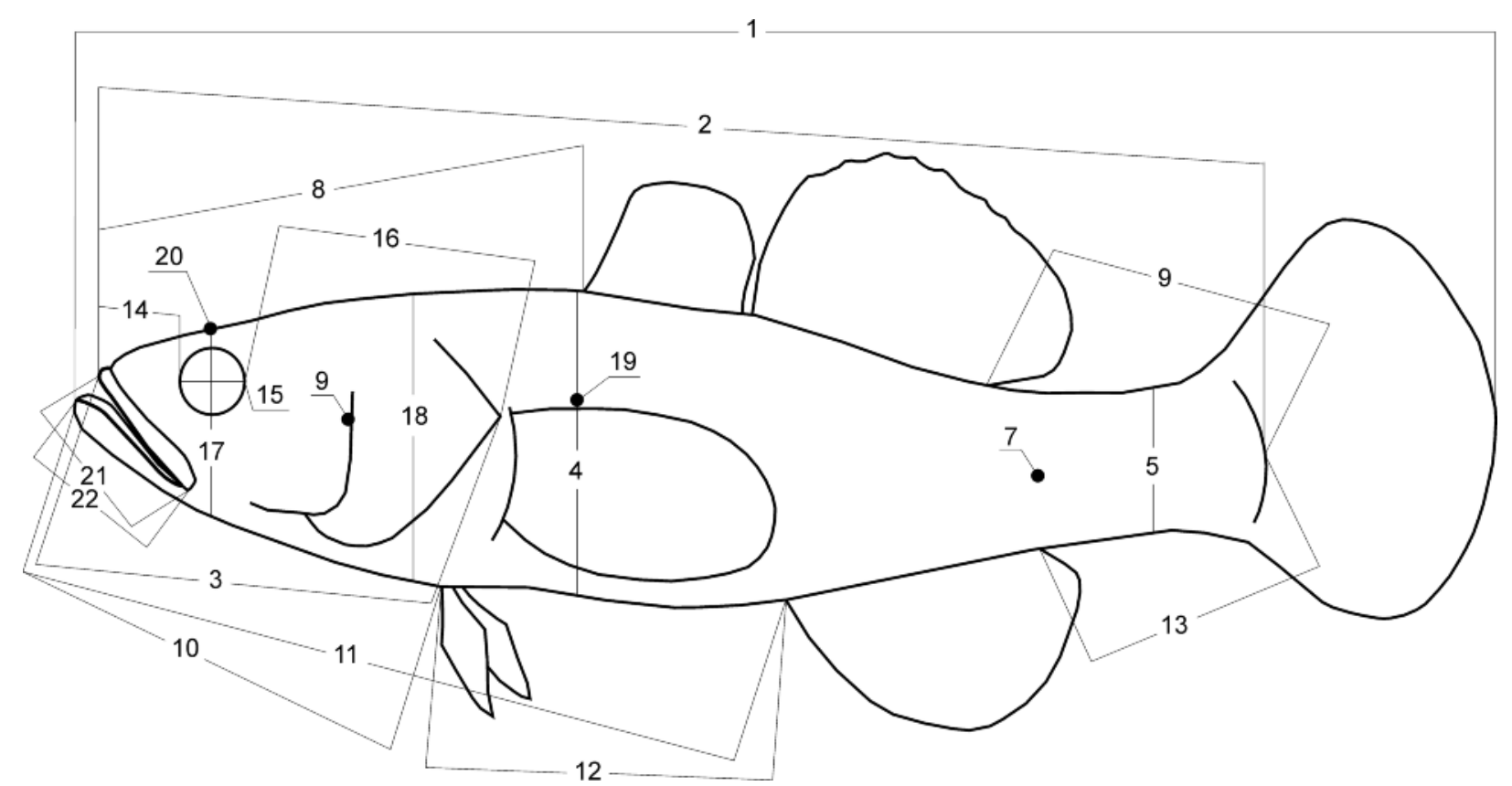

Fig. 2. Measurement diagram of the Perccottus glenii according to Hubbs and Lagler (1947) scheme; characters description as in Table 1

Meristic characteristics of Perccottus glenii caught in ponds in Kraków-Mydlniki $(n=36)$

Table 2

\begin{tabular}{|c|c|c|c|c|c|c|c|c|c|c|c|c|c|c|c|c|c|c|c|c|}
\hline \multirow{2}{*}{ Character } & \multicolumn{20}{|c|}{ Number of specimens with the character value } \\
\hline & 7 & 8 & 9 & 10 & 11 & 12 & 16 & 17 & 18 & 19 & 37 & 38 & 39 & 40 & 41 & 42 & 43 & 44 & 45 & 46 \\
\hline D1 & 1 & 32 & 3 & & & & & & & & & & & & & & & & & \\
\hline D2 & & & & 1 & 20 & 15 & & & & & & & & & & & & & & \\
\hline A & & & 1 & 7 & 24 & 4 & & & & & & & & & & & & & & \\
\hline $\mathrm{sq}$ & & & & & & & & & & & 2 & 3 & 11 & 10 & 8 & 2 & & & & \\
\hline $\mathrm{cf}$ & & & & & & & & & & & & & & & 5 & 12 & 10 & 6 & 2 & 1 \\
\hline $\mathrm{cp}$ & & & & & & & 1 & 10 & 20 & 5 & & & & & & & & & & \\
\hline
\end{tabular}

D1, number of rays in first dorsal fin; D2, number of rays in second dorsal fin; A, total number of rays in anal fin; sq, numbers of scales in lateral row; cf, circumference rows of scales; $\mathrm{cp}$, cicumpeduncular rows of scales.

Circumference (cf) and circumpeduncular (cp) rows of scales were counted, respectively, in advance of the dorsal fin and at the lowest point of the caudal peduncle.

The occurrence of $P$. glenii in ponds in KrakówMydlniki denotes the invasive character of this species. It is potentially dangerous not only to the fishes, but also to the other indigenous animals (Reshetnikov 2003). Furthermore, $P$. glenii has no economic importance, attaining only about $250 \mathrm{~mm}$ in total length and up to $250 \mathrm{~g}$ in weight, though the most specimens do not exceed $120 \mathrm{~mm}$ total length (Berg 1949, Koščo et al. 2003, Reshetnikov 2003).

Its appearance and dispersal in Polish water bodies, simultaneously with other non-indigenous species (e.g., brown bullhead, Ameiurus nebulosus; pumpkinseed, Lepomis gibbosus; round goby, Neogobius melanostomus; and stone moroko, Pseudorasbora parva) could cause serious problems to the local fauna. P. glenii threat the native ichthyofauna by competition, displacement, and direct predation (Bogutskaya and Naseka 2002, Koščo et al. 2003, Witkowski 2003, Reshetnikov 2003, 2004, Kostrzewa et al. 2004, Copp et al. 2005). Furthermore, it has been demonstrated that this species may be a vector of certain parasites and fungi (Czeczuga et al. 2002, Koščo et al. 2003, Uzunova and Zlatanova 2007). Sustained monitoring of the spreading of this species is needed to prevent, if possible, new invasions (Witkowski 2003, Kostrzewa et al. 2004). Due to its resistance to adverse ecological conditions, gluttony and dispersal caused by floods (Bogutskaya and Naseka 2002, Koščo et al. 2003, Reshetnikov 2003, 2004, Kostrzewa et al. 2004) a consecutive dispersal of this species in the territory of Poland is expected, as well as in other regions of Eurasia.

The origin of the individuals of $P$. glenii collected in Kraków-Mydlniki is another question. They probably have been brought with juveniles of Carassius gibelio which were purchased a few times. The possibility of releasing them from aquarium cultures is also taken into account. Despite all efforts to annihilate all the specimens of $P$. glenii 
in ponds and to prevent its dispersal outside, some individuals were found in the draining ditches emptying to the Rudawa River, the left-bank tributary of the Vistula River. It could cause a new invasion to the Rudawa River system, and subsequently also the Vistula River. As far as we know, all attempts of eradication of $P$. glenii from various bodies of water have failed (Bogutskaya and Naseka 2002, Reshetnikov 2003, 2004), what does not make an optimistic prediction for the future.

\section{ACKNOWLEDGMENTS}

Special thanks are due to Dr Jerzy Szymacha, Dr Ewa Łuszczek-Trojnar, Dr Magdalena Socha, Dr Paweł Szczerbik, Mr. Krzysztof Tatoj, and Mr. Artur Klaczak of the Department of Ichthyobiology and Fisheries, Agricultural University of Krakow for their support with collecting and handling the material. The authors want to express their appreciation to Mrs. Karolina Woźniak and Mrs. Izabela Woźniak for the linguistic revision, and to the two anonymous reviewers for their valuable remarks on the manuscript.

\section{REFERENCES}

Andrzejewski W., Mastyński J. 2004. Nowe stanowisko trawianki (Perccottus glenii Dybowski 1877). [A new site of the Chinese sleeper (Perccottus glenii Dybowski 1877).] Komunikaty Rybackie 2004 (2): 22-23. [In Polish.]

Antychowicz J. 1994. Perccottus glehni [sic] w naszych wodach. [Perccottus glehni [sic] in our waters.] Komunikaty Rybackie 1994 (2): 21-22. [In Polish.]

Berg L.S. 1949. Ryby presnyh vod SSSR i sopredel'nyh stran. [Fishes of the USSR and adjacent countries.] Vol. 3. Moskva-Leningrad. [In Russian.]

Bogutskaya N.G., Naseka A.M. 2002. Perccottus glenii Dybowski, 1877. In: Freshwater fishes of Russia, Zoological Institute RAS. http://www.zin.ru/Animalia/pisces/eng/taxbase_e/species_e/ /perccottus/perccottus_glenii_eng.pdf.

Copp G.H., Bianco P.G., Bogutskaya N.G., Erős T., Falka I., Ferreira M.T., Fox M.G., Freyhof J., Gozlan R.E., Grabowska J., Kováč V., Moreno-Amich R., Naseka A.M., Peňáz M., Povž M., Przybylski M., Robillard M., Russell I.C., Stakėnas S., Šumer S., Vila-Gispert A., Wiesner C. 2005. To be, or not to be, a non-native freshwater fish? Journal of Applied Ichthyology 21: 242-262.

Czeczuga B., Kiziewicz B., Danilkiewicz Z. 2002. Zoosporic fungi growing on the specimens of certain fish species recently introduced to Polish waters. Acta Ichthyologica et Piscatoria 32: 117-126.

Freyhof J. 2003. Immigration and potential impacts of invasive freshwater fishes in Germany. Berichte des IGB 17: 51-58.

Hegediš A., Lenhardt M., Mićković B., Cvijanović G., Jarić I., Gačić Z. 2007. Amur sleeper (Perccottus glenii Dybowski, 1877) spreading in the Danube River Basin. Journal of Applied Ichthyology 23: 705-706.

Hubbs C.L., Lagler K.F. 1947. Fishes of the Great Lakes Region. Bulletin of the Cranbrook Institute of Science 26: 1-186.

Jurajda P., Vassilev M., Polačik M., Trichkova T. 2006. A First Record of Perccottus glenii (Perciformes:
Odontobutidae) in the Danube River in Bulgaria. Acta Zoologica Bulgarica 58: 279-282.

Kakareko T. 1999. Perccottus glenii Dybowski 1877 (Odontobutidae) w Zbiorniku Włocławskim na dolnej Wiśle. [Perccottus glenii Dybowski 1877 (Odontobutidae) in Włocławski Dam Reservoir on the lower Vistula River.] Przegląd Zoologiczny 42: 107-110. [In Polish.]

Kostrzewa J., Marszal L., Tłoczek K. 1999. Czy trawianka Percottus glenii ma szansę stać się trwałym elementem polskiej ichtiofauny? [Could the Chinese sleeper, Percottus glenii, become a permanent element of the Polish ichthyofauna?] Chrońmy Przyrodę Ojczystą 55 (5): 98-101. [In Polish.]

Kostrzewa J., Grabowski M., Zięba G. 2004. Nowe inwazyjne gatunki ryb w wodach Polski. [New invasive fish species in Polish waters.] Archives of Polish Fisheries 12 (Suppl. 2): 21-34. [In Polish.]

Koščo J., Lusk S., Halačka K., Lusková V. 2003. The expansion and occurrence of the Amur sleeper (Perccottus glenii) in eastern Slovakia. Folia Zoologica 52: 329-336.

Panov V., Leppakoski E., Ojaveer H. 1999. Introduction of alien species into the Gulf of Finland - an increasing environmental problem. In: Regional Biological Invasions Center. http://www.zin.ru/projects/invasions/gaas/aliens3r.htm.

Plikšs M., Aleksejevs E. 1998. Zivis. [Fishes]. Gandrs, Riga. [In Latvian.]

Reshetnikov A.N. 2003. The introduced fish, rotan (Perccottus glenii), depresses populations of aquatic animals (macroinvertebrates, amphibians, and fish). Hydrobiologia 510: 83-90.

Reshetnikov A.N. 2004. The fish Perccottus glenii: history of introduction to western regions of Eurasia. Hydrobiologia 522: 349-350.

Terlecki J. 1995. Percottus glenii Dybowski 1877 (Pisces, Eleotridae) w Polsce. [Percottus glenii Dybowski 1877 (Pisces, Eleotridae) in Poland.] P. 163. In: Proceedings of the 11th Congress of the Polish Zoological Society, 14-16 September 1995, Łódź, Poland. [In Polish.]

Terlecki J. 2000. Trawianka Perccottus glenii Dybowski, 1877. [Chinese sleeper, Perccottus glenii Dybowski, 1877.] Pp. 476-479. In: Brylińska M. (ed.) Ryby słodkowodne Polski [The freshwater Fishes of Poland.] PWN, Warszawa. [In Polish.]

Terlecki J., Palka R. 1999. Occurrence of Perccottus glenii Dybowski, 1877 (Perciformes, Odontobutidae) in middle stretch of the Vistula River, Poland. Archives of Polish Fisheries 7: 141-150.

Uzunova E., Zlatanova S. 2007. A review of the fish introductions in Bulgarian freshwaters. Acta Ichthyologica et Piscatoria 37: 55-61.

Witkowski A. 2003. Amur sleeper (Perccottus glenii). In: Solarz W. (ed.) Alien species in Poland. http://www.iop.krakow.pl/ /ias/species.asp?215.

Woźniewski M. 1997. Trawianka - nowy gatunek ryby w Wiśle. [Chinese sleeper - a new fish species in the Vistula River.] Wiadomości Wędkarskie 1997 (12): 69. [In Polish.]

Received: 29 November 2007 Accepted: 20 March 2008 Published electronically: 20 June 2008 